\title{
Depth Determınatıon From Gravıty Data Usıng Radıal Amplıtude Spectrum: The Dikili (İmir) Geothermal Area
}

\author{
Emre Timur $^{1}$ iD $\cdot$ Coşkun Sarı ${ }^{1}$ D
}

Received: 17 July 2020 / Accepted: 20 January 2021 / Published online: 17 March 2021

(c) The Author(s) 2021

\begin{abstract}
The Dikili geothermal area, in the northern part of Izmir province, is one of the best known geothermal areas in Western Anatolia. This study attempts to analyze and interpret Bouguer gravity data to determine average structural depth values and assess geothermal resources using the Radial Amplitude Spectrum Method (RASM), based on 2D Fast Fourier Transform (FFT) analysis. We selected four different areas to apply the method. The greatest advantage of this method over the conventional power spectrum method is that it can determine the mean depth from 2D FFT spectra, not using a single cross-section taken in one direction. Thus, the user can select an area rather than a direction and average depth can be determined more accurately. The results show that average depth values of the top of the reservoir vary between 314 and $640 \mathrm{~m}$ in the region.
\end{abstract}

Keywords Dikili $\cdot$ Fourier transform $\cdot$ Geothermal $\cdot$ Gravity $\cdot$ Radial amplitude spectrum

\section{Introduction}

Geothermal energy is environmentally friendly, costeffective, sustainable and reliable, but has historically been limited to areas near tectonic plate boundaries. Recent technological advances have expanded the range of viable resources, particularly for applications such as greenhouse and home heating, opening the potential for widespread exploitation. Geothermal water production releases greenhouse gases trapped deep within the Earth. However these emissions are much lower per unit of energy production than those of fossil fuels.

Dikili is a tourist city in İzmir province, Western Anatolia, Turkey. Thermal waters in Dikili and the nearby historical city of Bergama (ancient Pergamon) have been used for spas, therapy and bathing from ancient times as far back as the Hellenistic Period (Fig. 1). Nowadays, as well as being used for balneology, these waters can also be developed for district and greenhouse heating for culvitation and aquaculture $[1,2]$. The thermal waters between Dikili and Bergama have outlet temperatures of $25-58{ }^{\circ} \mathrm{C}$. Locally, high arsenic contents pose an environmental problem, and hence the

Coşkun Sarı

coskun.sari@deu.edu.tr

1 Engineering Faculty, Department of Geophysics, Dokuz Eylül University, Buca, İzmir, Turkey water cannot be used for drinking [3]. Earlier geothermal exploration studies of Dikili vicinity were evaluated together with the neighboring town of Bergama [4-9]. Dikili city has become the second largest tourist and agricultural centre in Bakırçay after Bergama, with a population of about 44,000. Residential heating mostly uses coal that has recently caused serious environmental problems such as air pollution. A more ecconomically and environmentally attractive alternative for residential heating is the utilization of geothermal energy.

Structural features of geothermal systems are different from oil and gas systems where the fluids are stored in the pores of permeable formations and confined by impermeable rock. They are also different from groundwater systems, which can be either confined, unconfined or in perched aquifers. Geothermal systems are more complex, less defined, and their type and extent can only be determined through exploration drilling and well testing [10]. Geothermal systems can be described as a combination of units in which water is used as a transport agent, through which the heat is taken from the sources in the ground and transmitted to the consumer. The main elements of a geothermal system are a source of heat, a tank (reservoir) and transporting fluid, usually water. The main objective of geophysical studies in geothermal exploration is to determine and model the physio-chemical properties of the geothermal system and its elements, particularly the reservoir. 


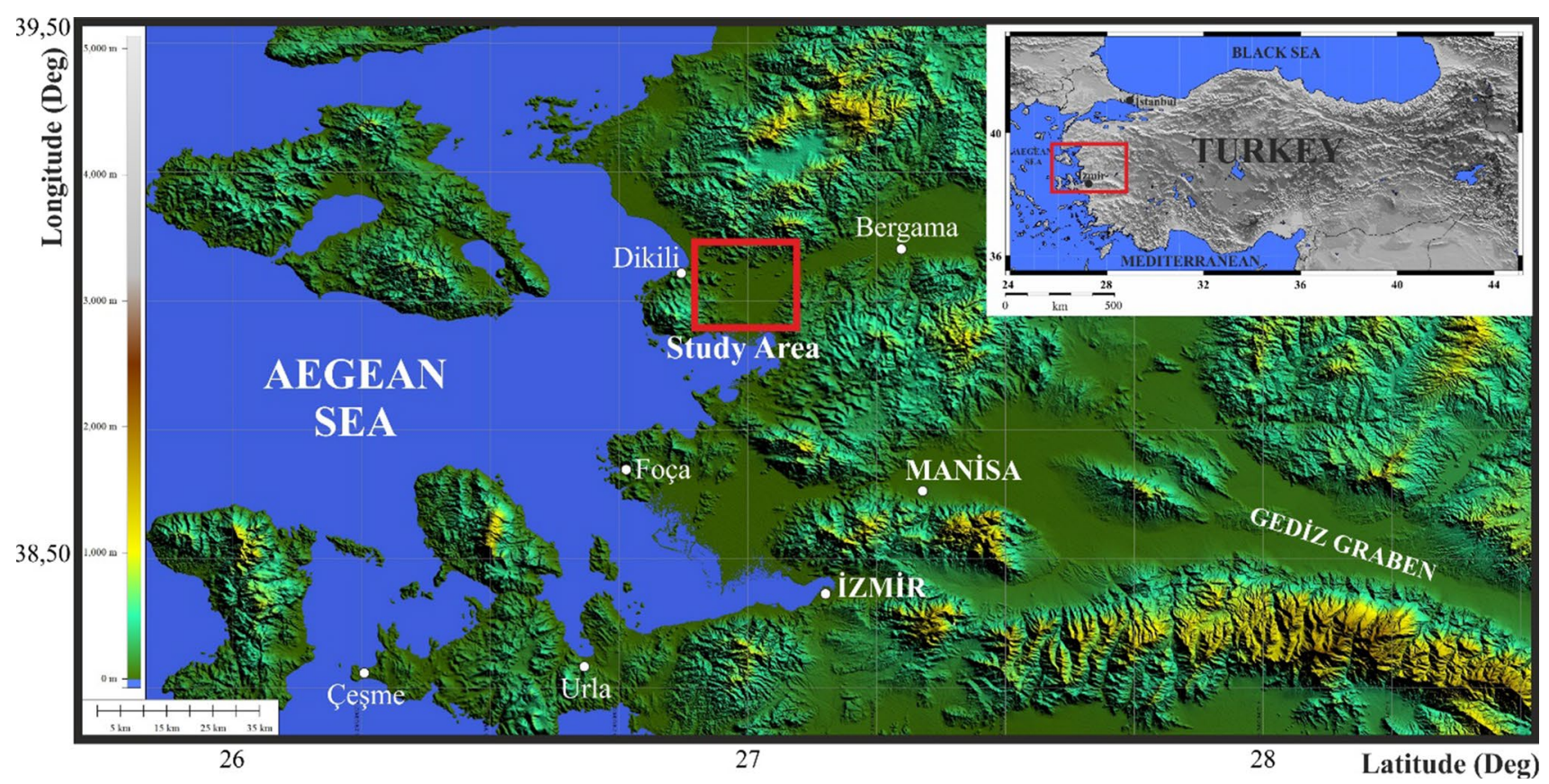

Fig. 1 Topography of the Turkish Aegean region, showing the location of the Dikili geothermal area

The interpretation of gravity data mainly aims to estimate the location and depth of the source structure causing the anomaly. Different underground structures can give the same gravitational field on the surface, which causes the interpretation to be ambiguous. For this reason, methods aiming to distinguish shallow and deep structures are generally used for separating regional and residual anomalies. These methods include smoothing with simple operators, digital filters, derivative methods, analytical continuations and trend analysis [11-13]. To determine structural boundaries where sudden changes cause anomalies, the use of boundary analysis methods, first applied by Cordell and Grauch [14, 15], have become common in recent years. These methods can be used for direct interpretation, as well as to provide preliminary information for derivative or other common modeling studies. However, it is possible to obtain a singular solution if a certain preliminary information about the geometry of the causal source is available [16-20]. One method that can be used for this purpose is the Spectral Factorization Method, which is based on the assumption that the underground geological layer interfaces are approximately horizontal [21, 22]. The gravity effect of such structures is expressed by the first derivative term of Parker's [23] relation in the frequency domain. If there is more than one prismatic source over the surface topography, the power spectrum of these prismatic structures reveals a quasi-linear relationship between wave number $(\mathrm{kT})$ and spectral density, and this principle is used in depth determination.

In the present study, the Radial Amplitude Spectrum method was applied to the gravity data collected in Dikili geothermal area, and the results were compared with previous 3D modeling studies and well data. The study area was previously investigated by MTA in 1980s [6], and here we aim to determine the depth of the reservoir for further possible drilling locations. This study is the first application to the research area using this data processing technique.

\section{Geological and Hydrogeological Settings}

The study area lies in the Bakırçay graben, one of the main Western Anatolia graben systems. The geology of the Dikili region includes basement rocks, Kozak pluton, Yuntda volcanics, pyroclastic rocks, Dededağ basalts and alluvium [24] (Fig. 2a). The oldest units are Permian Çamoba and Lower Triassic Kınık formations [6]. These are mainly limestones and siltstones. The stratigraphic sequences continue upwards with the Eocene to Oligocene Kozak granodiorite, Middle Miocene Yuntdağ volcanics-I and II, Upper Miocene Yeniköy formation and Upper Miocene to Pliocene Yuntda $\breve{g}$ volcanics-III. The oldest Yuntdağ volcanics-I consists of widely altered andesite. The Tertiary Yuntdağ volcanicsII are mainly felsic pyroclastics covering the Yuntdağ volcanics-I. This unit is covered with the youngest Yuntdağ volcanics-III (Tyu-III) [3], comprising biotite hornblendebiotite andesite. Quaternary alluvium is the youngest unit of the area. The Yuntdağ volcanics-I form the reservoir rocks of the geothermal systems of the area. The Yuntdağ volcanicsII including poorly cemented pyroclastics has relatively low 

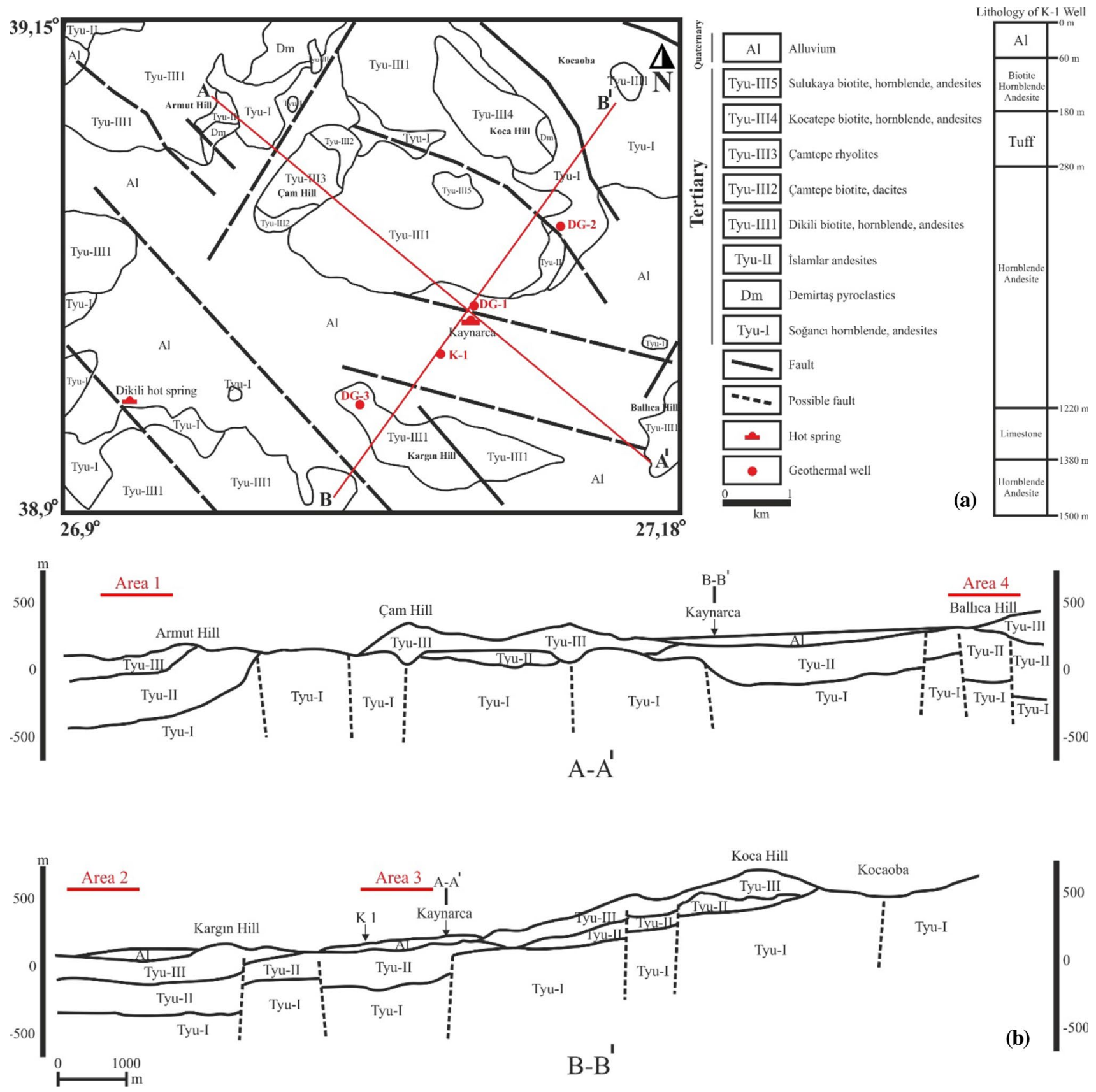

Fig. 2 a Geology of Dikili-Kaynarca geothermal area (modified from [28-30]), b A-A ${ }^{1}$ and B-B ${ }^{1}$ cross sections (modified from [29])

permeability due to altered clayey levels and may act as cap rocks for the geothermal systems of Dikili.

Metamorphic basement units, Mesozoic conglomerates, sandstone and recrystallized limestone olistoliths surround the Kozak pluton, andesitic volcanoclastic rocks, undifferentiated sub-volcanic domes and Yürekli dacites. The hypabisal granodiorite porphyry intrusions are of Early Miocene age [25]. The Pliocene Demirtaş pyroclastic unit is seen around Dikili hot spring. These rocks cover the Yuntdag volcanics-I and are less than $100 \mathrm{~m}$ thick. Following the westward tectonic escape of the Anatolian-Aegean plate and N-S Aegean extension, important geothermal systems formed in the graben and tectonic zones in Western Anatolia during the Miocene and Pliocene. The Dikili-Kaynarca geothermal area is such an area within this horst-graben system [26]. NW-SE, NE-SW trending faults are predominant in the Kaynarca geothermal area (Fig. 2).

The gravity studies showed that the fault in the north forming the graben extends E-W through Dikili-Kaynarca and the fault bounding the south of Bakırçay graben 
passes north of Kargin Hill [27]. Further geological and geochemical studies were carried out to identify active faults and compositional and physical properties of the geothermal waters in the area. The geochemical studies included temperature and gas $\left(\mathrm{CO}_{2}\right)$ measurements and hydrothermal alteration and isotope studies. It was found that the surface E-W fault and graben are cut by SW-NE trending faults where geothermal resources are present in the region [6]. A geological map of the Dikili-Kaynarca showing formations and faults is given in Fig. 2a.

Several geothermal wells were drilled in the late 1980s by the General Directorate of Mineral Research and Exploration of Turkey (MTA). DG-1, DG-2 and DG-3 wells, drilled in 1987, have a depth of $200 \mathrm{~m}$ and water temperature of 30 to $45^{\circ} \mathrm{C}$. The Kaynarca-1 (K-1) well was drilled in 1989 to a depth of $1500 \mathrm{~m}$. The temperature reached $130{ }^{\circ} \mathrm{C}$ the water flow was too low to be productive at K-1. The Soğanc1 hornblende andesite (Tyu-I), with a depth of $280 \mathrm{~m}$, is the reservoir formation for thermal water at this location (Fig. 2a). The locations of selected areas overlying the two geological cross-sections are shown in Fig. $2 \mathrm{~b}$.

In the fault zones, descending groundwater is heated by conduction by magma at depth. Fluids reach the surface as gas $\left(\mathrm{CO}_{2}\right)$ and steam to supply surface geothermal resources $[4,29]$. The Yuntdağ volcanic unit intersects the neighboring Kozak Massif in the northwest of the area, and overlies a dome-shaped subvolcanic structure in the graben. Geothermal activity is in the form of hot springs around the area.

The geothermal system in the region is characterized by recharge of meteoric waters in the Kozak region that descend into the subsurface along tectonic lines, heating up at depth and resurfacing along the faults and fractures. The highest source temperature in the Dikili Geothermal Field is $58{ }^{\circ} \mathrm{C}$ in the depth range $0-100 \mathrm{~m}$. These waters contain bicarbonates, sodium sulphate and carbon dioxide. Dikili geothermal waters emerge from fractures related to an E-W fault and surface at several places on the alluvial strip. High-temperature springs discharged from the alluvium at the sites of dark colored andesites of the Yuntdag volcanites [26]. Hot springs in the region were affected by the $1939 \mathrm{M}_{\mathrm{w}} 7.9$ Erzincan earthquake. Some of the hot springs that appeared were short-lived while others have remained stable since 1939.

The hot water springs are ideal for regional thermal heating and agricultural greenhouses [4]. Today, 600 acres of greenhouses are heated by geothermal water near the Kaynarca and Çamur thermal springs. The residential heating project of Dikili Municipality started at the beginning of 2008. There are also some studies of electricity generation. As of 2020, 15 licensed wells shallower than $150 \mathrm{~m}$ are operated by the Dikili Municipality, İzmir Governorate and Greenhouse Enterprises.

\section{Radial Amplitude Spectrum Method}

The radial amplitude spectrum method is based on the spectrum of buried objects that have density differences relative to their surroundings. The radial amplitude is the average $A=|F|=\left[\operatorname{Re}(F)^{2}+\operatorname{Im}(F)^{2}\right]^{1 / 2}$ of the 2D Fourier amplitude spectrum calculated along circles with radius $k_{r}=\left[k_{x}^{2}+k_{y}^{2}\right]^{1 / 2}$ and center $k_{x}=k_{y}=0$, where A respresents the amplitude, $\mathrm{F}$ the Fourier transform, Re and Im are the real and imaginary parts of the transform and $\mathrm{k}$ represents the wavenumber.

Thomson [31] studied the energy and strength of the signal with the help of Parseval theory. The amplitude spectrum has traditionally been used to determine depth to potential field sources. This is achieved by passing through the amplitude curve plotted on a semi-logarithmic scale. In the frequency domain, the Fourier transform of a potential field is defined by $F=\mathrm{Ce}^{-\mathrm{hk}}$, from which $\log \left(\frac{F}{C}\right)=-\mathrm{hk}_{r}$ can be written. Thus, the depth $(h)$ from the surface to the structure causing the anomaly is equal to the tangent of the slope of the linear portions of the amplitude spectrum. For general data types, $C$ is taken as 1 and the logarithm of the vertical axis amplitude spectrum is calculated. $C=-1 /\left(k_{x} k_{y} k\right)$ is used for gravity data and $C=-1 /\left(k_{x} k_{y}\right)$ is used for magnetic data. Details can be found in [32]. Due to different calculations of data types, depth estimates differ [33].

The method has many applications to both theoretical and field data related to gravity and magnetic methods [34]. Theoretical details about the application of RASM to depth estimation are given by Bhattacharyya [35], Ruotoistenmaki [36], Naidu and Mathew [37] and Pirttijärvi [38].

Odegard and Berg [39] defined the method for simple structures, and Bhattacharyya and Leu [33] adapted it for complex shaped structures, using the gravity field power spectrum to determine the depth to the center of the structure. When the calculated spectrum is plotted semi-logarithmically, the slope of the spectrum gives the depth to the center of the mass [13].

A two-dimensional spectrum may be expressed in condensed form as two one-dimensional spectra, a radial spectrum and an angular spectrum. The radial spectrum is defined as

$\left.R_{f}(s)=\frac{1}{2 \pi} \int_{0}^{2 \pi} S_{f}(s \cdot \cos (\theta)), s \cdot \sin (\theta)\right) d \theta$

where $s=\sqrt{\left(u^{2}+v^{2}\right)}$ and $\theta=\tan ^{-1}(v / u)$ are polar coordinates and angular spectrum is defined as

$A(\theta)=\frac{1}{\Delta s} \int_{s_{0}}^{s_{0}+\Delta s} S_{f}(s \cdot \cos (\theta)), s \cdot \sin (\theta) d s$ 
where $\Delta s$ is the radial frequency band starting from $s_{0}$ to $s_{0}+\Delta s$, over which averaging is carried out. The $u$ and $v$ are horizontal and vertical coordinates respectively. In order to free the angular spectrum of any radial variation, a normalization process with respect to the radial spectrum is applied. Thus, the angular spectrum is expected to bring out the angular variations of the 2D spectrum of the potential fields, such as gravity. We normalized the spectrum with respect to the radial spectrum (Eq. 1) and then define the angular spectrum as

$A_{\text {Norm }}(\theta)=\frac{1}{\Delta s} \int_{s_{0}}^{s_{0}+\Delta s} \frac{S_{f}(s \cdot \cos (\theta), s \cdot \sin (\theta))}{R_{f}(s)} d s$

Calculation of the radial and angular spectra requires averaging the $2 \mathrm{D}$ spectrum over concentric rings. The average of the radial and angular spectra tend to be smooth functions and peaks in the angular spectrum indicate linear features in the map. The radial spectrum is a measure of the rate of decay of the amplitude spectrum which may represent a deep seated structure [40].

\section{Results}

Various data processing and modeling methods such as edge detection and 3-D inversion were previously applied to data obtained from digitization with $0.05 \mathrm{~km}$ grid spacing of the Bouguer gravity anomaly map $[6,27]$ of the geothermal area

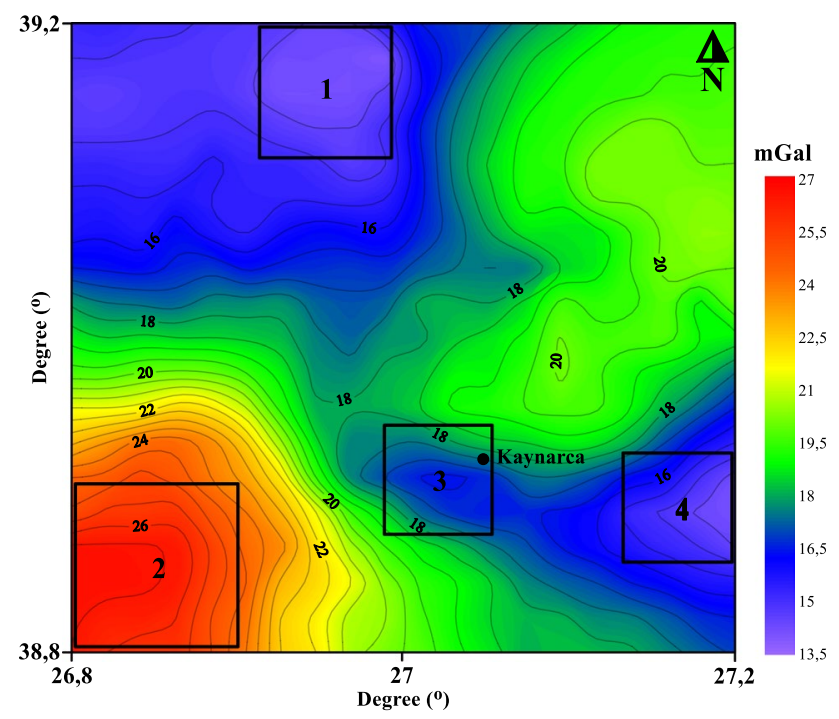

Fig. 3 Bouguer gravity anomaly map of the Dikili geothermal area [6] $($ Contour interval $=0.5 \mathrm{mGal})$ at Dikili (Fig. 3) [41, 42]. In this study, the radial spectral depths of 4 different parts of the research area were calculated and compared with the previous findings.

The selected areas for depth calculation are the areas where intensive and detailed geothermal surveys are planned in thermal tourism facilities and for agricultural and residential heating in Dikili and Bergama. In order to calculate the radial amplitude spectrum for data in this region, 2D Fast Fourier Transform (FFT) was performed. The 2D Fourier analysis maps calculated for areas 1,2,3 and 4 are presented in Figs. 4, 5, 6, 7, respectively. According to FFT theory, the dimensions $(\mathrm{N} \times \mathrm{M})$ of the four selected areas are automatically shifted to multiples of 2 by external value finding. Thus, even if the selected area is rectangular, the calculation still can be performed. The field selection is made as full frame so that the external value finding process is equal in all directions.

Radial spectra were calculated and plotted after 2D-FFT transforms of all selected areas had been performed. The spectral values obtained from these maps and depths calculated for the two structures are given in Fig. 8a-d.

The structural depths to the near-surface units (Alluvium and Tyu-III) for areas 1-4 were calculated to be $95 \mathrm{~m}, 86 \mathrm{~m}$, $66 \mathrm{~m}$ and $71 \mathrm{~m}$ respectively. The depths of the structures representing the topography of reservoir units (Tyu-I) in

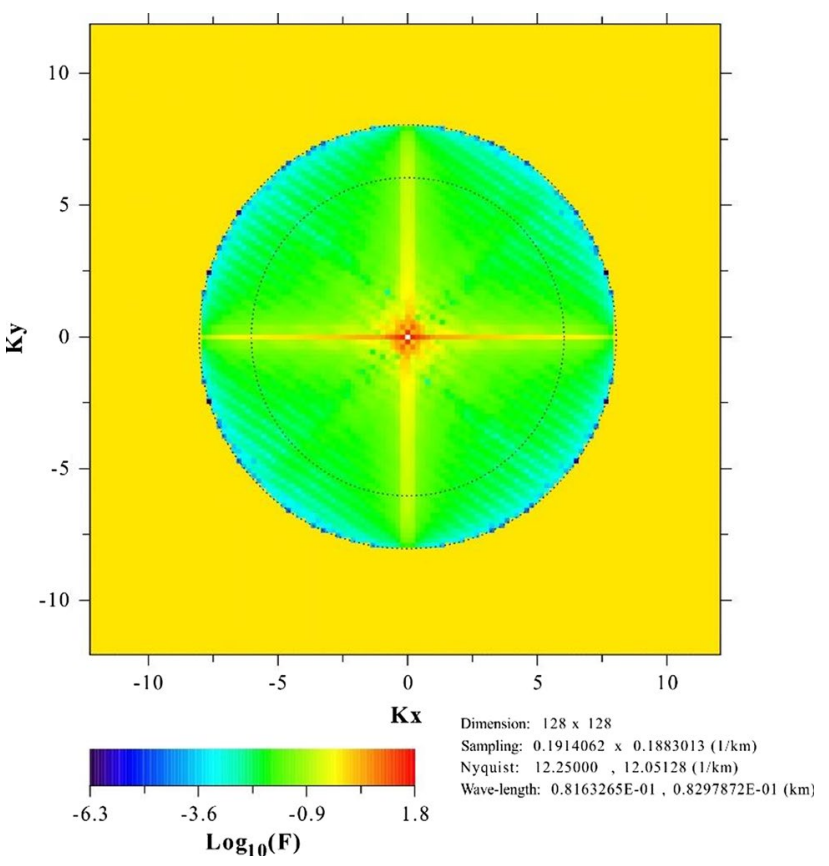

Fig. 4 2D Fourier transform map of area 1 


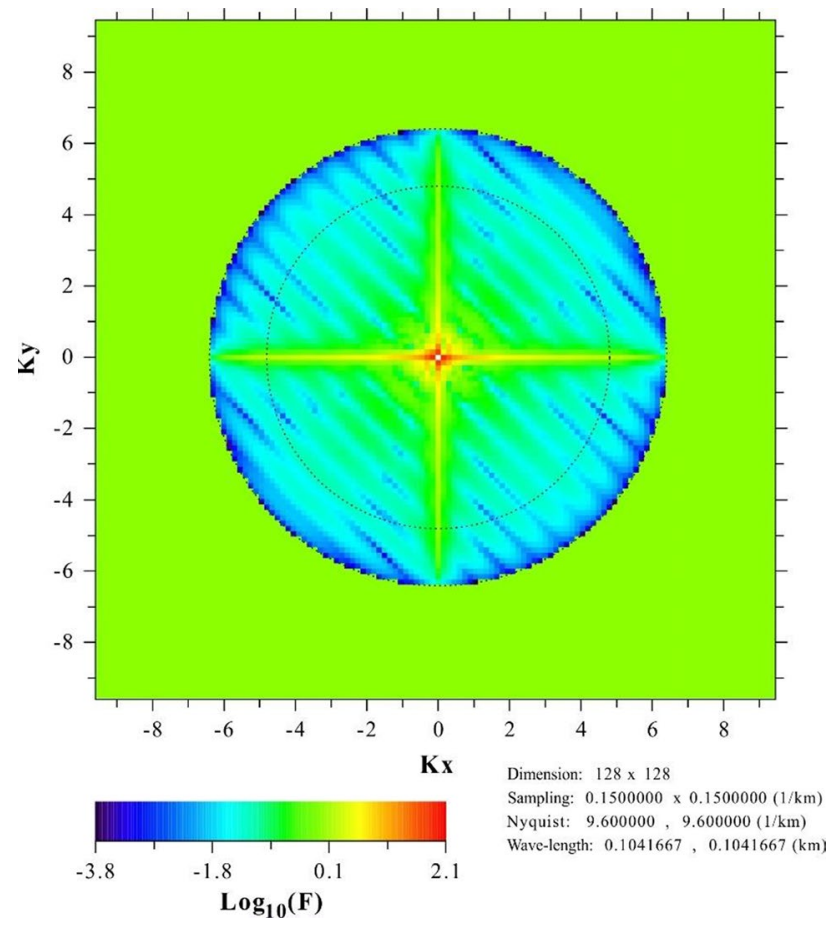

Fig. 5 2D Fourier transform map of area 2

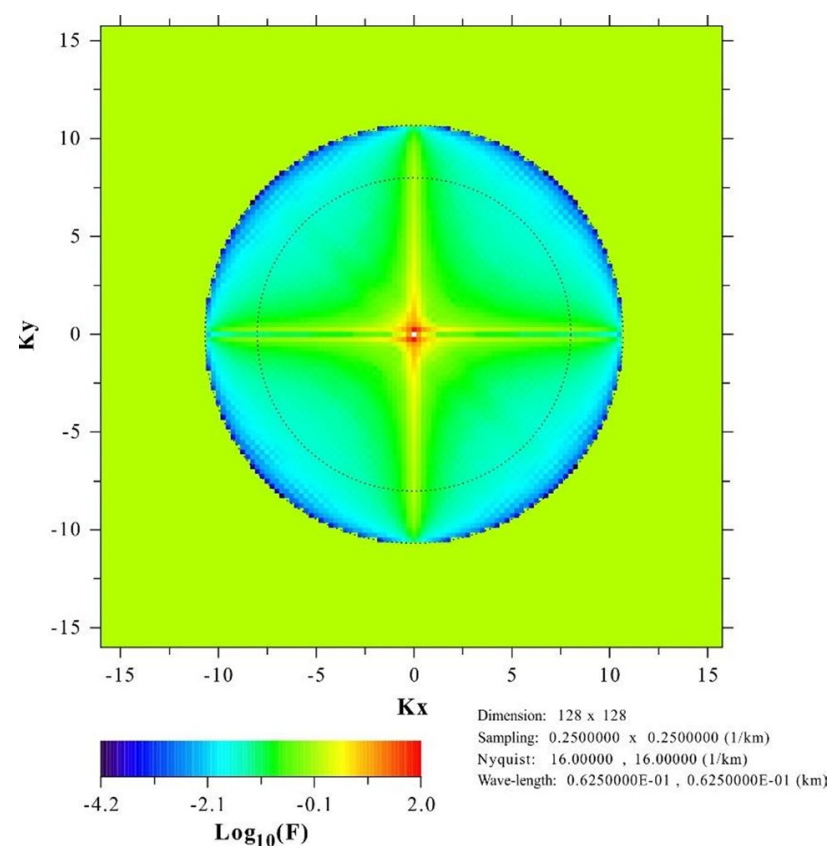

Fig. 6 2D Fourier transform map of area 3

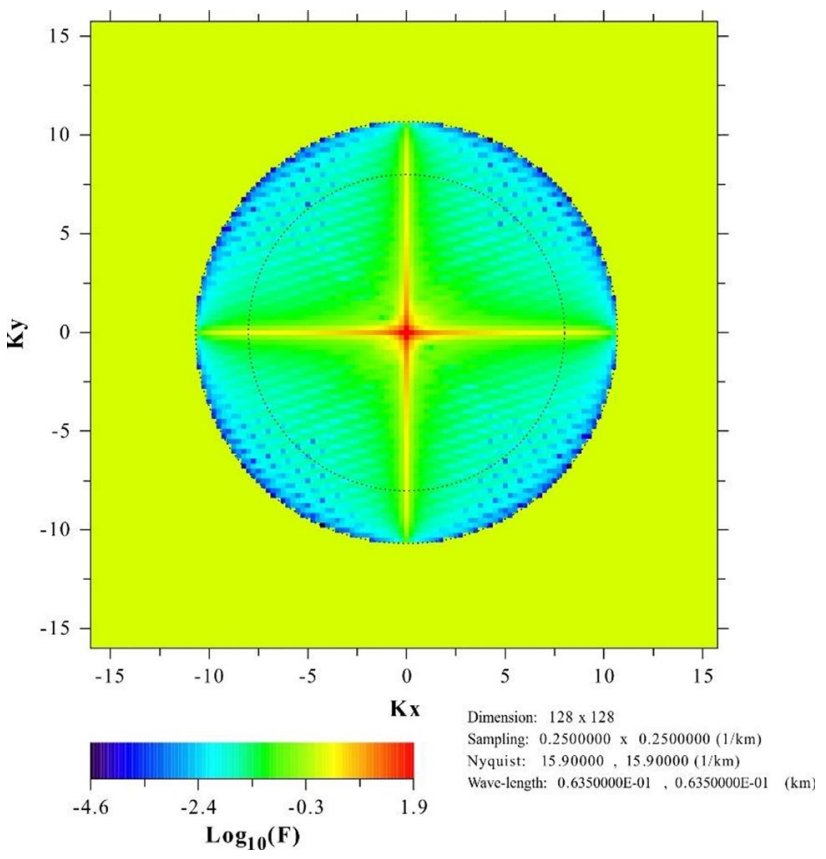

Fig. 7 2D Fourier transform map of area 4

the same areas were found to be $638 \mathrm{~m}, 618 \mathrm{~m}, 314 \mathrm{~m}$ and $552 \mathrm{~m}$.

Area 1, covering the Bouguer anomaly with low gravity values measured on the coastal side at the northernmost part of the study area, was investigated first, followed by the other areas. All depths determined by RASM were compatible with the maximum depth of $650 \mathrm{~m}$ calculated by Y1lmaz and Sar1 [40] using 3D gravity evaluation software developed by Murthy and Rao [43]. The differences between the calculated values in this study and those of the study of Y1lmaz and Sar1 [41] vary between 11 to $25 \mathrm{~m}$ at the centers of the four areas (Table 1). The calculated shallow depths represent the young cover formations of Alluvium and Tyu-III and the deeper ones represent the depth of the Tyu-I formation which functions as a reservoir in the selected areas. These findings are important for future detailed geothermal studies in the study area.

\section{Discussion and Conclusions}

We mapped gravity data in the Dikili geothermal area in four different areas. 2D Fourier transform was applied to selected spatial data and then RASM was carried out to obtain the 
Fig. 8 (a) Radial amplitude spectrum values and calculated depths of a Area 1, b Area 2, c Area 3 d Area 4. Kr represents radial wavenumber $(1 / \mathrm{km})$ and $\mathrm{F} / \mathrm{C}$ represents the ratio of the logarithm of the amplitude spectrum to the parameter $\mathrm{C}$

regional and residual depths. Area 1 was evaluated to determine the effect of alluvium between Dikili town center and the Kızılçukur-Kabakum line. The maximum calculated depth in this area was $638 \mathrm{~m}$ and the thickness of the alluvium cover layer was considerably higher compared to the area in general.

Area 2 was evaluated to investigate the effect of hornblende-biotite andesite of the Dikili and Soğancı formations in the area to the west and south of Dikili hot spring and east and south of Dikili town. In this area, where the highest gravity values were measured, the second deepest value was calculated as $618 \mathrm{~m}$. This indicates that the Tertiary volcanic units observed on the surface continue in the subsurface. According to the geological characteristics of the region from MTA-JICA reports, this depth is the boundary between Dikili andesites (Tyu-III1) and Soğancı andesites (Tyu-I). The superficial structural depth, calculated as $86 \mathrm{~m}$ for the same area, is thought to be alluvium and pyroclastic cover whose thickness is less than $100 \mathrm{~m}$ from geological studies. These transition zones are also of great importance for the geothermal structure of the region.

Area 3 corresponds to the alluvial area on the DikiliOvacik line including the Kaynarca hot water outlets and $\mathrm{K}-1$ well. The depth of the reservoir in this area is calculated as $314 \mathrm{~m}$, which is the shallowest in the study area. This value corresponds to the Soğanc1 andesites (Tyu-I). It is measured as $280 \mathrm{~m}$ in the log of well K-1. Alluvial thickness in the area is $66 \mathrm{~m}$, and measured as $60 \mathrm{~m}$ in the well log.

Area 4 corresponds to the alluvial area on the Aşağıkırıklar-Ovacık-Bergama line. There is intense agricultural activity in this region and the topography is flat. This is the region of the lowest gravity values in the study area. The thickness of alluvium and Tyu-II unit is calculated as $550 \mathrm{~m}$.

All calculated depths are consistent with values obtained from 3D modeling and geological studies in the field, as presented in cross-sections. Since the radial amplitude spectrum method is applied over 2D data, it is not necessary to decide the direction of the cross-section as is the case for conventional power spectra. The method reflects the mean of a spatial effect and regardless of whether we use gravity or magnetic data, the results change due to the $\mathrm{C}$ parameter in the theory. The method is extremely fast and reliable and will be useful in future for the evaluation of potential field data.
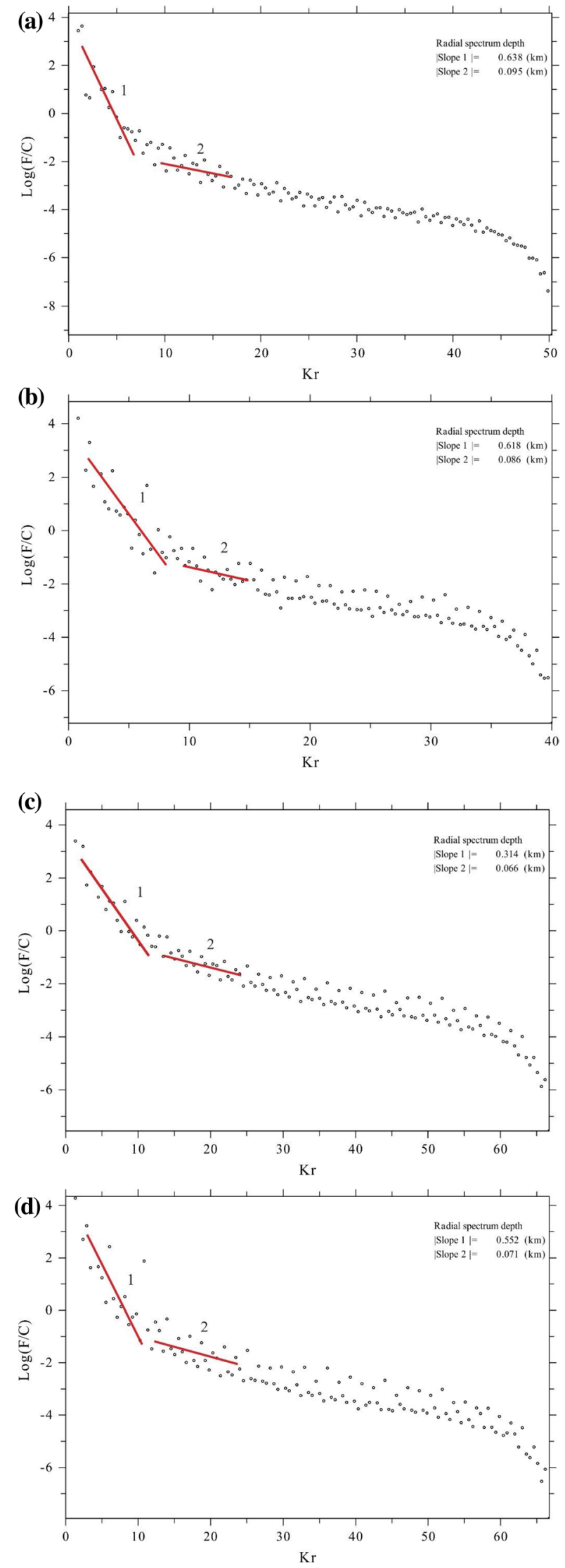
Table 1 Comparison of RASM estimation results, previous geophysical studies and drilling data

\begin{tabular}{|c|c|c|c|c|c|}
\hline \multicolumn{2}{|c|}{ Area } & $\begin{array}{l}\text { RASMEs- } \\
\text { timation } \\
\text { (m) }\end{array}$ & $\begin{array}{l}\text { Sarı and } \\
\text { Y1lmaz, } 2017 \\
\text { (m) }\end{array}$ & $\begin{array}{l}\text { Drilling } \\
\text { data }(\mathrm{m})\end{array}$ & Lithology \\
\hline \multirow[t]{2}{*}{1} & Shallow & 95 & - & - & $\begin{array}{l}\text { Alluvium, Tyu- } \\
\text { III1 }\end{array}$ \\
\hline & Deep & 638 & 650 & - & Tyu-I \\
\hline \multirow[t]{2}{*}{2} & Shallow & 86 & - & - & $\begin{array}{l}\text { Alluvium, Tyu- } \\
\text { III1 }\end{array}$ \\
\hline & Deep & 618 & 607 & - & Tyu-I \\
\hline \multirow[t]{2}{*}{3} & Shallow & 66 & - & 60 & Alluvium \\
\hline & Deep & 314 & 329 & 280 & Tyu-I \\
\hline \multirow[t]{2}{*}{4} & Shallow & 71 & - & - & Alluvium \\
\hline & Deep & 552 & 539 & - & Tyu-I \\
\hline
\end{tabular}

Acknowledgements We thank the subject editor for editorial handling of the manuscript, and to the three anonymous reviewers. We are grateful to Prof. Dr.Emin Uğur ULUGERGERLİ for his constructive criticism on the manuscript, We are also grateful to Prof. Dr. Gillian Foulger of University Durham (UK) for improving the English language and geological terminology of the manuscript.

Open Access This article is licensed under a Creative Commons Attribution 4.0 International License, which permits use, sharing, adaptation, distribution and reproduction in any medium or format, as long as you give appropriate credit to the original author(s) and the source, provide a link to the Creative Commons licence, and indicate if changes were made. The images or other third party material in this article are included in the article's Creative Commons licence, unless indicated otherwise in a credit line to the material. If material is not included in the article's Creative Commons licence and your intended use is not permitted by statutory regulation or exceeds the permitted use, you will need to obtain permission directly from the copyright holder. To view a copy of this licence, visit http://creativecommons.org/licenses/by/4.0/.

\section{References}

1. Lund, J.W.: Introduction to Geothermal Aquaculture. In: Dickson, M.H.; Fanelli, M. (Eds.) Geothermal Energy Utilization and Technology. Earthscan, London (2006)

2. Dikel, S.; Öz, M.: Use of geothermal sources in aquaculture. In: International Congress on Advances in Veterinary Sciences \& Technics (ICAVST), 25-29 August 2016, Sarajevo, Bosnia and Herzegovina, 122 (2016)

3. Tarcan, G.; Gemici, Ü.: Hydrogeochemical Assessment of the Bergama Thermal Waters, İzmir, Turkey. In: Proceedings World Geothermal Congress 2010, Bali, Indonesia, 25-29 April 2010, pp. 1-10 (2010)

4. Yilmazer, S.: Dikili-Bergama (İzmir) Geothermal Field of Turkey. In: Seminar on Utilization of Geothermal Energy for Electric Power Production and Space Heating, Florence (Italy) (1984)

5. Y1lmazer, S.; Özgüler, M.E.: Geological and Geophysical Studies in the Dikili Bergama. İzmir) Geothermal Field of Turkey, MTA, Ankara (1986)

6. MTA-JICA: Pre-Feasibility Study on the Dikili Bergama Geothermal Development Project in the Republic of Turkey. General
Directorate of Mineral Research and Exploration (MTA), Progress Report II, Final Report, Ankara (1987) (in Turkish)

7. Filiz, Ş.; Tarcan, G.; Gemici, Ü.: Dikili-Bergama (İzmir) Jeotermal Alanları'nın Hidrojeolojik İncelenmesi, Mining Congress of Turkey, 2-6 November 1998, MTA-Ankara, Book of Abstracts, pp. 487-508 (2000) (in Turkish)

8. Özen, T.; Tarcan, G.; Gemici, Ü.: Hydrogeochemical Study of the Selected Thermal and Mineral Waters in Dikili Town, İzmir, Turkey. In: Proceedings, World Geothermal Congress 2005 Antalya, Turkey, 24-29 April, 0898, pp. 1-12 (2005)

9. Sarı, C.; Y1lmaz, Y.: The Geothermal Potential of BergamaDikili Region and Evaluation of the Gravity Data. 9th Congress of the Balkan Geophysical Society, Extended Abstract, 5-9 Nov. (2017)

10. Zarrouk, S.J.; McLean, K.: Geothermal systems Geothermal Well Test Analysis Fundamentals. Appl. Adv. Techniq. https:// doi.org/10.1016/B978-0-12-814946-1.00002-5

11. Henderson, R.G.; Zeitz, I.: The upward continuation of anomalies in total magnetic intensity fields. Geophysics 14, 517-534 (1949)

12. Fuller, B.D.: Two dimensional frequency analysis and grid operators: mining. Geophysics 2, 658-708 (1967)

13. Blakely, R.J.: Potential theory in gravity and magnetic applications, p. 441. Cambridge University Press, Cambridge (1995)

14. Cordell, L.; Grauch, V.J.S.: Reconciliation of the discrete and integral fourier transform. Geophysics 47, 237-243 (1982)

15. Cordell, L.; Grauch, V.J.S.: Mapping basement magnetization zones from aeromagnetic data in the San Juan Basin New Mexico. In: Hinze, W.J. (Ed.) The utility of regional gravity and magnetic anomaly maps, pp. 181-197. Soc of Exploration Geophysics, Tulsa (1985)

16. Blackman, R.B.; Tukey, J.W.: The measurement of power spectrum, p. 190. Dover Publications, New York (1959)

17. Cooley, J.W.; Tukey, J.W.: An algorithm for the machine computation of complex Fourier series. Math. Comput. 19, 297-301 (1965)

18. Naidu, P.S.: Spectrum of potential fields due to randomly distributed sources. Geophysics 33, 337-345 (1980)

19. Telford, W.M.; Geldart, L.; Sheriff, R.E.; Keys, D.A.: Applied Geophysics, 2nd edn. Cambridge University Press, Cambridge (1990) https://doi.org/10.1017/CBO9781139167932

20. Roy, L.; Agarwal, B.N.P.; Shaw, R.K.: A new concept in Euler deconvolution of isolated gravity anomalies. Geophys. Prospect. 48(3), 559-575 (2000). https://doi.org/10.104 6/j.1365-2478.2000.00203.x

21. Spector, A.; Grant, F.S.: Statistical models for interpreting aeromagnetic data. Geophysics 35, 293-302 (1970)

22. Studinger, M.; Kurinin, R.G.; Aleshkova, N.D.; Miller, H.: Power Spectra Analysis of Gravity Data from the Weddell Sea Embayment and Adjacent Areas. Terra Antartica 4(1), 23-26 (1997)

23. Parker, R.L.: The Rapid Calculation of Potential Anomalies. Geophys. J.R. Astr. Soc. 31, 447-455 (1972)

24. Eşder, T.: Kaynarca ve çamur 1lıcaları (Dikili) jeotermal alanları ve çevresinde bugüne kadar yapılan jeotermal araştırmalara ilişkin derleme raporu. MTA, Ankara (1998).

25. Yılmaz, H.; Oyman, T.; Arehart, G.B.; Çolakoğlu, A.R.; Billor, Z.: Low sulfidation type $\mathrm{Au}-\mathrm{Ag}$ mineralization at Bergama, İzmir Turkey. Ore Geol Rev 32, 81-124 (2007)

26. Özen, T.: Dikili Sıcak ve Soğuk Su Kaynaklarının Hidrojeolojik İncelemesi. Yüksek Lisans Tezi, D.E.Ü. Fen Bilimleri Enstitüsü, İzmir, 81 p. (2002) (Unpublished, with English abstract)

27. MTA-JICA: Pre-Feasibility Study on the Dikili-Bergama Geothermal Development Project in the Republic of Turkey. General 
Directorate of Mineral Research and Exploration (MTA), Progress Report I, Ankara (1986) (Unpublished-in Turkish)

28. MTA-JICA: Geothermal investigation report of Western Anatolia. General Directorate of Mineral Research and Exploration (MTA), Ankara (1990) (Unpublished-in Turkish).

29. MTA.: Inventory of geothermal sources of Turkey. General Directorate of Mineral Research and Exploration (MTA). Publication No:197, Ankara (1996) (in Turkish)

30. MTA.: Geological map of Turkey upon Scale: 1/500.000. General Directorate of Mineral Research and Exploration (MTA), Ankara, Turkey (2002)

31. Thompson, D.J.: Spectrum estimation and harmonic analysis. Proc. IEEE 70(7), 1055-1096 (1982)

32. Pirttijärvi, M.: Potential field data processing and analysis of using 2-D Fourier transform. Fourpot User's Guide, University of Oulu, 34-37 (2014)

33. Bhattacharyya, B.K.; Leu, L.K.: Spectral Analysis of gravity and magnetic anomalies due to two dimensional structures. Geophysics 40, 993-1013 (1975)

34. Likkason, O.K.: Spectral Analysis of Geophysical Data, Advances in Data, Methods, Models and Their Applications in Geoscience, Dr. DongMei Chen (Ed.), ISBN: 978-953-307737-6, InTech, Available from: http://www.intechopen.com/ books/advances-in-data-methods-models-and-their-applicatio ns-ingeoscience/spectral-analysis-of-geophysical-data (2011)

35. Bhattacharyya, B.K.: Some general properties of potential fields in space and frequency domain; a review. Geoexploration $\mathbf{5}$, 127-143 (1967)
36. Ruotoistenmaki, T.: Estimation of depth to potential field sources using the Fourier amplitude spectrum. PhD thesis, Bulletin 340, Geological Survey of Finland. (1987)

37. Naidu, P.S.; Mathew, M.P.: Digital analysis of aeromagnetic maps: detection of a fault. J. Appl Geophys 38, 169-179 (1998)

38. Pirttijärvi, M.: Numerical modeling and inversion of geophysical electromagnetic measurements using a thin plate model. $\mathrm{PhD}$ thesis, Acta Univ. Oul. A403, University of Oulu (2003)

39. Odegard, M.E.; Berg, J.W.: Gravity interpretation using the Fourier integral. Geophysics 30(3), 424-438 (1965)

40. Naidu, P.S.; Mathew, M.P.: Advances in Exploration Geophysics, Chapter 3-Analysis of geophysical potential fields. Springer Pub. ISBN: 978-0-444-82801-9. pp. 75-143 (1998b)

41. Yılmaz, Y.; Sarı, C.: Bergama-Dikili Bölgesinin Gravite Verilerinin Değerlendirilmesi ve Jeotermal Potansiyeli. 90 Yılın Ardından İstanbul Üniversitesi'nde Jeofiziğin Serüveni Sempozyumu, 10-12 May 2017, Book of Abstracts, p. 35 (2017) (In Turkish with English Abstract)

42. Yılmaz, Y.: Bergama-Dikili Jeotermal Alanının Gravite Verilerinin Yorumu. MSc Thesis. Dokuz Eylul University, İzmir, p. 69. (2018) (In Turkish with English Abstract)

43. Murthy, I.V.R.; Rao, P.R.: Inversion of gravity and magmatic anomalies of two dimensional polygonal cross section. Comput. Geosci. 19, 1213-1228 (1993) 